\title{
Human Governance for Teaching at Higher Learning Institution in Malaysia
}

\author{
Dr. Lim Gee Nee (Corresponding Author) \\ Senior Lecturer, KDU University College Penang, Jalan Anson, 10700 Georgetown \\ Penang, Malaysia \\ Email: gnlim08@gmail.com
}

Dr. Lee Mun Seng

Professor, Quest International University Perak, Jalan Raja PermaisuriBainun, 30250

Ipoh, Perak. Malaysia

Email: purextsb@gmail.com

Received: January 12, 2016 Accepted: January 21, 2016 Published: February 20, 2016

doi:10.5296/jpag.v6i1.8849 URL: http://dx.doi.org/10.5296/jpag.v6i1.8849

\begin{abstract}
Human governance is getting rampant in many professional bodies; it involves personal behaviour, thinking and conduct. Teaching at higher learning institution is very crucial to our younger generation, human governance could provide a holistic wholeness approach for higher learning institution to yield a group of dynamic graduate that could find jobs earlier and work happily.
\end{abstract}

Keywords: Human governance, University, College, Teaching, Learning, Administration 


\section{Introduction}

Human governance (HG) is important for our daily life and career. It is defined as "an internal, inside-out and values-based conviction to guide the human as the sentient being to behave whereas corporate governance is an external, outside-in rules and regulations to legislate the behaviour of corporation, as a legal person. Human governance looks at the axiology, encompassing the traits of values, religion, belief system, culture, and ethics in order to foster a culture based on trust where human within the organization is viewed as the soul of the organization" (Salleh and Ahmad, 2010). In fact, Salleh and Ahmad (2010) successfully distinguish between $\mathrm{HG}$ and corporate governance (CG), they are compared and summarised as Table 1 below:

Table 1: Corporate Governance Vs Human Governance

\begin{tabular}{|c|c|}
\hline $\begin{array}{c}\text { Corporate Governance (For the } \\
\text { Legal/Artificial Person) }\end{array}$ & $\begin{array}{l}\text { Human Governance(For the } \\
\text { Sentient/Spiritual Being) }\end{array}$ \\
\hline - Discovery & - Disclosure \\
\hline - $\quad$ Translucent & - Transparent \\
\hline - Conformance & - Beyond conformance \\
\hline - Caveatemptor & - Edicovenditor \\
\hline - Dead & - Emergent \\
\hline - Symbol & - $\quad$ Meaning \\
\hline - Label & - Essence \\
\hline - Form & - Substance \\
\hline - $\quad$ Rule-based & - $\quad$ Principle-\&values-based \\
\hline - Legal enactments & - Innatenature (fitrah) \\
\hline - $\quad$ Rules \&compliance & - Good conduct \& beyond compliance \\
\hline - Newtonian classical & - Quantum science \\
\hline - $\quad$ Fragmented & - Wholeness \\
\hline
\end{tabular}

(Salleh and Ahmad, 2010)

\section{Important of Human Governance}

HG is deemed to be the core principal for professional conduct, this can be applicable in the scope of teaching and administration. Other forms of governance may be essential in many professions, but HG should be a priority especially in teaching. A holistic HG approach is vital, ethical behaviour should be part of the factors of implementation and consideration 
(ArfahSalleh and Aziuddin Ahmad, 2010).

Malaysia is a multiracial country, everyone has one's own personal belief, religion, thinking, culture, way of working and uniqueness. In teaching, HG is towards to personalization, adaptation to others and human behaviour oriented approach. HG is involved with three tiers in teaching, i.e., the higher management, colleagues and students; it assists teachers achieving the required standard for education and development as set by the higher management, helping their colleagues gaining their goal together and sustain their duty for their students in the current society.

HG encourages teachers to think out of the box, it does not restrict teachers with rules and regulation. As long teachers are complying with the spirit of the law and doing no harm to their superiors, fellow colleagues and students, any form of advancement, suggestion and improvement are greatly appreciated. With implementation of HG in teaching, teacher's decision is focused on human well being and student's interest. It should neutralise and balance the effect between corporate money making maximisation and preaching of adequate knowledge to our students, the education bubble in the other countries is a good example.

In many countries, their higher education institutions are highly profit driven, their courses are mostly market oriented. They are CG based, their interests are towards the benefit of the corporate demand. It is portrayed to the public that without a degree chance to be in poverty would be at least three time higher (Eichler, 2011), this created a strong desire for the young students to take educational loan in order to be enrolled in a prospective degree. Unfortunately with the unforeseeable economic downturn, the student's has hit at least four hundred and sixty (460) billion United States Dollar (USD), nearly thirty percent (30\%) of fresh graduates are jobless (Colombo, 2015).Globally many countries are facing a regretful consequence of over CG, education has become a cause of misery for students.

In Malaysia, our consideration should be driven towards our culture and religion. HG could play a great role to find a balance between corporate yielding and student's interest. With an appreciate HG with the higher management, courses should be designed towards student's interest and belief, good profit to the higher institution and firm fulfilment to the job market demand. Teachers should not be restricted to use their ways to teach, as long it is complying with their belief and doing no harm to anyone, they are free to exchange ideas with their follow colleagues. A good HG would allow teachers to share their knowledge as tailored to student's interest and belief, students are encouraged to think out of box in order to gain their wisdom. HG may lead Malaysia to a better environment of teaching, similar bubble in USA may not be seen.

\section{Application of Human Governance for Teaching at Higher Institutions in Malaysia}

HG in teaching is definitely more convincing than CG because student and public interests are put as a priority. Students enjoy their study without any comprise on their belief, they could find a job readily after graduation as tailored to their and the market demand. However, achieving this goal needs a strong commitment and corporate metamorphosis; the corporate must be ready to evolve and accept the new dimension of management, they should be open 
for transformation and consider a new framework. Later, they may discover HG bringing fun, productivity and resiliency in teaching (Kofman, 2013).

In short, my application of HG in teaching is outlined as in Table 2 as below:

Table 2: Application of Human Governance in Teaching

3 Tiers

\begin{tabular}{|c|c|c|}
\hline Higher Management & Colleagues & Students \\
\hline $\begin{array}{l}\text { Design courses oriented to } \\
\text { student's interest and market } \\
\text { demand }\end{array}$ & $\begin{array}{l}\text { Respect and accept other's } \\
\text { belief and background } \\
\text { without confrontation }\end{array}$ & $\begin{array}{l}\text { Respect and accept student's } \\
\text { belief and background } \\
\text { without confrontation }\end{array}$ \\
\hline Open for suggestion & Open for suggestion & Open for suggestion \\
\hline Open for criticism & Open for criticism & Open for criticism \\
\hline $\begin{array}{l}\text { Transparent policy to } \\
\text { students and teachers }\end{array}$ & $\begin{array}{l}\text { Transparent to higher } \\
\text { management and colleagues }\end{array}$ & Transparent to students \\
\hline $\begin{array}{l}\text { Seek balance between } \\
\text { corporate finance and } \\
\text { student's interest }\end{array}$ & $\begin{array}{l}\text { Seek teaching balance } \\
\text { between yourself and } \\
\text { colleague's interest }\end{array}$ & $\begin{array}{l}\text { Seek teaching balance } \\
\text { between yourself and } \\
\text { student's interest }\end{array}$ \\
\hline $\begin{array}{l}\text { No restriction on teaching } \\
\text { method as long it is complied } \\
\text { with professional conduct } \\
\text { and basic rules and } \\
\text { regulations }\end{array}$ & $\begin{array}{l}\text { Respect your colleague's way } \\
\text { of teaching }\end{array}$ & $\begin{array}{l}\text { Respect your student's } \\
\text { feedback on teaching and } \\
\text { improve accordingly to gain } \\
\text { their interest }\end{array}$ \\
\hline $\begin{array}{l}\text { Respect teachers and students } \\
\text { as a holistic wholeness rather } \\
\text { slave or money making } \\
\text { instrument }\end{array}$ & $\begin{array}{l}\text { Respect your neighbour as a } \\
\text { holistic wholeness rather than } \\
\text { rival }\end{array}$ & $\begin{array}{l}\text { Respect your students as a } \\
\text { holistic wholeness rather than } \\
\text { apprentice }\end{array}$ \\
\hline
\end{tabular}

\section{Conclusion}

In my personal opinion, $\mathrm{HG}$ is more superior than $\mathrm{CG}$ in teaching, it encourages research, innovation and creativity. It is focused on personal behaviour, belief, thinking and conduct, it enhances flexibility on teaching and learning. Robotic way of CG certainly is not ideal for implementation on teaching because its rigidity restricts brainstorming. 


\section{Reference}

Salleh, A\& Ahmad, A. 2010. Human Governance: Bringing the Meaning of Integrity in the Life of Professional Accountants. In Articles of Merit E-Book (pp. 30-39). New York: International Federation of Accountants (IFAC).

Colombo, J. 2015. The College Bubble. Retrieved from: http://www.thebubblebubble.com/college-bubble/

Eichler, A. August 30, 2011. Hiring Is Up For The Class Of 2011, But Previous Classes Still Struggle. New York, USA: Huffington Post.

Kofman, F. 2013. Conscious Business: How to Build Value through Values. Colorado: Sounds True.

\section{Copyright Disclaimer}

Copyright for this article is retained by the author(s), with first publication rights granted to the journal.

This is an open-access article distributed under the terms and conditions of the Creative Commons Attribution license (http://creativecommons.org/licenses/by/3.0/). 